\title{
Bioalapú epoxigyanta kompozitok környezetkímélő égésgátlása
}

\author{
SZOLNOKI Beáta* \\ Budapesti Müszaki és Gazdaságtudományi Egyetem, Szerves Kémia és Technológia Tanszék, \\ Budafoki út 8., 1111 Budapest, Magyarország
}

\section{Bevezetés}

A rendelkezésünkre álló kőolaj-tartalékok mennyiségének csökkenésével, és a környezettudatos gondolkodásmód elterjedésével egyre erőteljesebb az igény olyan polimer kompozitok kifejlesztésére, amelyek megújuló nyersanyagforrásból származnak és az életciklusuk végén újrahasznosíthatók, vagy biodegradálhatók. Míg a hőre lágyuló mủanyagok között egyértelmű a politejsav térnyerése, addig a hőre keményedő polimerek esetében még várat magára az ipari környezet számára is megfelelő megoldás. A növényi olaj alapú vegyületeknek, ${ }^{1,2}$ valamint a ligninből előállítható epoxi monomereknek ${ }^{3,4}$ szerteágazó irodalma van, ugyanakkor mindkét vegyületcsaládnak vannak olyan hátrányos tulajdonságai ${ }^{5}$ (az előbbiek esetén az alacsony üvegesedési hőmérséklet, utóbbiaknál a nehezen reprodukálható szerkezet), amelyek akadályozzák az elterjedésüket müszaki alkalmazásokban. A cellulózszármazékok közül az izoszorbid-alapú epoxi monomer áll a kutatók figyelmének középpontjában, ${ }^{6,7}$ ugyanakkor eddig még ezzel a vegyülettel sem sikerült átütő eredményt elérni. Kutatócsoportunkban sikeresen állítottunk elő D-glükóz alapú epoxigyantákat ${ }^{8}$, melyek mechanikai tulajdonságaikban megközelítik az elterjedten alkalmazott biszfenol-A alapú epoxigyanta értékeit ${ }^{9}$.

Az epoxigyantákat kedvező tulajdonságaiknak köszönhetően (pl. szívósság, kémiai, mechanikai és elektromos ellenállás) szerteágazóan alkalmazzák a különböző iparágak, elsősorban azok, ahol az epoxigyanták által kínált müszaki előnyök kompenzálni tudják a többi hőre keményedő gyantához képest magasabb árukat (pl. elektronikai, ill. szállítási, fuvarozási ipar). Az egyre szigorodó biztonsági követelmények miatt felmerült az igény olyan megújuló nyersanyagforrásból származó, égésgátolt kompozitok előállítására, amelyek a fent említett iparágak mechanikai és égésgátlási követelményeit egyaránt kielégítik.

A korábban széles körben elterjedt, de az egészségre káros és korrozív hatású halogéntartalmú égésgátló anyagokkal szemben elsősorban a foszforszármazékok jelentenek a környezetre kevésbé ártalmas hatású alternatívát. A foszforszármazékokat adalék vagy monomer formában alkalmazva viszonylag kis mennyiségben is kedvező hatás érhető el. A foszfortartalmú égésgátló rendszerek a szilárdvagy a gázfázisban, illetve sok esetben mindkettőben kifejtik a hatásukat. Az égés során keletkező foszfortartalmú gázok kevésbé toxikusak, mint a halogéntartalmú égésgátlók bomlástermékei, ${ }^{10}$ valamint a keletkező foszforsav a degradálódott polimerrel reagálva egy stabil, elszenesedett felületi réteget alkot. ${ }^{11} \mathrm{E}$ tulajdonságok miatt a foszfortartalmú égésgátlók jelentősége egyre nagyobb.
A szorbit a glükóz hidrogénezésével előállított cukoralkohol, amely hat $\mathrm{OH}$-csoportot tartalmaz hat C-atomon. A hidroxilcsoportok epiklórhidrinnel történő reakciójával a már kereskedelmi forgalomban kapható szorbit poliglicidil éterhez (SPE) jutunk. A következőkben az SPE-alapú gyanták és kompozitok környezetbarát égésgátlási lehetőségei kerülnek bemutatásra.

\section{Kísérleti anyagok és módszerek}

\subsection{Felhasznált anyagok}

A bioepoxi mátrix előállításához Erisys GE-60 (Emerald Performance Materials) típusú, 160-195 g/ekv epoxi ekvivalensü, $25^{\circ} \mathrm{C}$-on $8000-18000 \mathrm{mPas}$ viszkozitású szorbit poliglicidil étert (SPE) térhálósítottuk. Térhálósító komponensként négyféle amin típusú vegyületet alkalmaztunk: egy aromás, egy cikloalifás, egy alifás és egy foszfortartalmú amint. Aromás vegyületként a Sigma-Aldrich által gyártott 4,4'-diaminodifenilmetánt (DDM, amin hidrogén ekvivalens: $49,6 \mathrm{~g} / \mathrm{eq}$, op. $88-92^{\circ} \mathrm{C}$ ), cikloalifásként az IPOX Chemicals MH3122 típusú, 464-490 mg KOH/g aminszámú, $\quad 25^{\circ} \mathrm{C}$-on $\quad 80-120 \quad \mathrm{mPas}$ viszkozitású 3,3'-dimetil-4,4'-diaminodiciklohexilmetánt (korábbi kereskedelmi neve T-58) használtuk. Az alifás térhálósító a Dow Chemical Company által gyártott DEH 24 márkanevü trietilén-tetramin (TETA, amin hidrogén ekvivalens: $24 \mathrm{~g} / \mathrm{eq}$, $25^{\circ} \mathrm{C}$-on mért viszkozitás: $19,5-22,5 \mathrm{mPas}$, és sürüség: 0,981 $\mathrm{g} / \mathrm{cm}^{3}$ ) volt, míg foszfortartalmú vegyületként a korábban elöállított ${ }^{12} \quad N, N^{\prime}, N^{\prime}$ '-trisz(aminoetil)foszforsavtriamidot (TEDAP, aminszám: $500 \mathrm{mg} \mathrm{KOH/g)} \mathrm{alkalmaztuk.}$

Égésgátló adalékanyagként APP-t (ammónium-polifoszfát), RDP-t (rezorcin-bisz(difenilfoszfát)), vörös foszfort (RP), DOPO-sav ammónium sóját (9,10-dihidro-10-hidroxi-9oxa-10-foszfafenantrén-10-oxid ammónium só, DXA) és DOPO-sav melamin sóját (9,10-dihidro-10-hidroxi9-oxa-10-foszfafenantrén-10-oxid melamin só, DXM) alkalmaztunk. Tulajdonságaikat az 1. táblázat foglalja össze.

1. táblázat. Az alkalmazott égésgátló adalékok tulajdonságai

\begin{tabular}{lllll}
\hline Jelölés & Márkanév & Gyártó & Megjelenés & $\begin{array}{l}\text { P-tartalom } \\
(\%)\end{array}$ \\
\hline APP & $\begin{array}{l}\text { NORD-MTN } \\
\text { JLS APP }\end{array}$ & $\begin{array}{l}\text { Nordmann } \\
\text { Rassmann1 } \\
\text { ICL Industrial } \\
\text { Products }\end{array}$ & $\begin{array}{l}\text { fehér por } \\
\text { sárgás } \\
\text { folyadék }\end{array}$ & $31-32$ \\
RDP & Fyrolflex RDP & 10,7 \\
RP & RP 6500 & Clariant & $\begin{array}{l}\text { vörosbarna } \\
\text { paszta } \\
\text { fehér por }\end{array}$ & $43-47$ \\
DXA & DXA-12 & Metadynea & $\begin{array}{l}12,0-12,5 \\
\text { fehér por }\end{array}$ & $8,4-8,7$ \\
\hline
\end{tabular}


Természetes szálerősítésként vászonszövésű lenszövetet, míg szénszál erősítésként a Zoltek Zrt. által gyártott PX35FBUD0300 típusú, módosítatlan unidirekcionális 50k-s rovingokból álló kötött kelmét alkalmaztuk. Előbbi esetben a kompozitok száltartalma 40\%, míg utóbbinál $60 \%$ volt. A természetes lenszövet égésgátló kezeléséhez diammónium-foszfátot és bórsavat (Sigma-Aldrich) használtunk.

\subsection{Alkalmazott mérési módszerek}

A térhálósító komponensek kiválasztásához a térhálósodási jellemzőket differenciális pásztázó kalorimetriával (TA Instruments DSC Q2000) tanulmányoztuk. Az első felfütésből a térhálósodás reakcióentalpiáját határoztuk meg, majd lehütés után a második felfütésböl az üvegesedési átmeneti hőmérsékletet.

A minták termikus stabilitását termogravimetriával vizsgáltuk, TA Instruments Q5000 típusú berendezésben, $10^{\circ} \mathrm{C} /$ perc fütési sebességgel $\mathrm{N}_{2}$ atmoszférában 25-800 ${ }^{\circ} \mathrm{C}$-ig. Mérésenként 15-20 mg mintát használtunk.

Az oxigénindex (OI) meghatározását az MSZ EN ISO 4589-1 és 4589-2 (2000) szabvány szerint végeztük.

UL-94 vizsgálat (ISO 9772 és ISO 9773) során a nehezen éghetö, vízszintesen, ill. függőlegesen befogott minták gyújtása alulról történik és mérni kell a láng kialvásához szükséges időt. Éghető anyag esetén a minta jellemzésére vízszintben mért lángterjedési sebesség szolgál. Csökkenő égési időkkel az égésgátoltsági fokozat $\mathrm{V} 2<\mathrm{V} 1<\mathrm{V} 0$ irányban nő.

A kaloriméteres éghetőségvizsgálatokat „mass loss” típusú Cone kaloriméterrel végeztük, ami az égés komplex jellemzőinek meghatározására szolgáló berendezés. A valós tüzesetekhez hasonló körülmények között meghatározható a minta gyulladási ideje, a kibocsátott hőmennyiség és az égés folyamata alatt a minta tömegvesztése. Méréseink során 25 $\mathrm{kW} / \mathrm{m}^{2}$ sugárzó hőnek tettük ki a $2 \mathrm{~mm}$ vastagságú mintákat (ISO 13927).

\section{Eredmények és értékelésük}

\subsection{Térhálósító komponens választása}

A megfelelő típusú térhálósító komponens kiválasztásához a szorbit-alapú epoxi monomert DSC-ben többféle kémiai szerkezetü aminnal reagáltattuk. Vizsgáltuk az amin vázának hatását a térhálósodásra, valamint az üvegesedési átmeneti hőmérsékletre (2. táblázat). Az alkalmazott aminok között található alifás (TETA), cikloalifás (T-58), aromás (DDM), valamint a korábban előállított égésgátló hatású TEDAP ${ }^{12}$ is.

Ahogy várható, a térhálósodás kezdeti hőmérséklete az alifás<cikloalifás<aromás irányban nő, az aminocsoportok mozgékonysága és hozzáférhetősége miatt. Az alifás aminok (TETA és TEDAP) esetén már szobahőmérséklet körül elkezdődik a térhálósodás, a cikloalifás T-58 esetén ehhez magasabb hőmérséklet szükséges, míg a szilárd halmazállapotú, aromás DDM (op. $88-92^{\circ} \mathrm{C}$ ) esetén mért közel $75^{\circ} \mathrm{C}$ arra utal, hogy próbatestek előállítása során mindenképp hőkezelésre van szükség a térhálósodási reakció beindításához. Az aromás és cikloalifás aminok alkalmazásakor meghatározott üvegesedési átmeneti hőmérsékletek lényegesen magasabbak, mint az alifás vegyületek esetén. Ez nyilvánvalóan az aminok szerkezetével függ össze: az aromás és cikloalifás gyürük merevebb szerkezete jobban gátolja a szegmensmozgást a térhálós gyantákban. A két alifás amin, a TETA és az égésgátló hatású TEDAP alkalmazásakor mért különbség szintén a molekulaszerkezetre vezethető vissza: az előbbi szénlánca az aminocsoportok között rövidebb, mint a P-tartalmú TEDAP esetében. A gélesedési idők tendenciája jó egyezést mutat a térhálósodás kezdeti hőmérsékletében megfigyelhető hatásokkal. A két alifás szerkezetü amin másfél-két perc alatt eléri a gélesedésnek megfelelő térhálósürüséget, a cikloalifás T-58 esetén ehhez majdnem 5 perc szükséges, míg a DDM-mel térhálósított rendszer esetén több, mint 25 percre van ehhez szükség.

2. táblázat. Az alkalmazott égésgátló adalékok tulajdonságai

\begin{tabular}{lllll}
\hline Térhálósító & TETA & T-58 & DDM & TEDAP \\
\hline $\begin{array}{l}\text { aminszám/amin- } \\
\text { hidrogén ekvivalens }\end{array}$ & $1440 / 24$ & $480 / 60$ & $-149,6$ & $500 /-$ \\
$\begin{array}{l}\text { térhálósodás kezdete } \\
\left({ }^{\circ} \mathrm{C}\right)\end{array}$ & 33,3 & 51,5 & 74,6 & 36,4 \\
exoterm csúcs $\left({ }^{\circ} \mathrm{C}\right)$ & 66,3 & 87,2 & 106,8 & 68,0 \\
$\begin{array}{l}\text { mért térhálósodási } \\
\text { entalpia }(\mathrm{J} / \mathrm{g})\end{array}$ & 331,7 & 346,4 & 376,6 & 228,5 \\
$\begin{array}{l}\text { üvegesedési } \\
\text { átmeneti } \\
\text { hőmérséklet }\left({ }^{\circ} \mathrm{C}\right)\end{array}$ & 98,6 & 124,4 & 133,7 & 74,0 \\
$\begin{array}{l}\text { gélcsedćsi idő } 80^{\circ} \mathrm{C}- \\
\text { on (sec) }\end{array}$ & 98 & 395 & 1550 & 130 \\
\hline
\end{tabular}

Az elsődleges cél az égésgátlás volt, ezért a megfelelő térhálósító komponens kiválasztásához az egyes aminok éghetőségre gyakorolt hatását is tanulmányoztuk. Ehhez oxigénindex, és UL-94 éghetőségvizsgálatoknak vetettük alá a négyféle aminnal térhálósított mintákat. A vizsgálatok eredményét a 3 . táblázat tartalmazza.

Az eredmények alapján megállapíthatjuk, hogy az alifás, illetve cikloalifás aminnal térhálósított minták könnyen éghetőek. Az oxigénindex értékek kicsik, illetve az UL-94-es vizsgálat esetén vízszintesen végigégtek, a lángterjedési sebességük 29, illetve $20 \mathrm{~mm}$ /perc. Az aromás, és a foszfortartalmú aminok esetén a mért oxigénindexek nagyobbak, valamint vízszintesen nem égtek végig a minták. A csökkent éghetőség várható volt, ugyanakkor kiemelkedő eredményt egyik esetben sem sikerült elérni.

3. táblázat. A különböző aminokkal térhálósított SPE éghetősége

\begin{tabular}{lll}
\hline Térhálositó & OI (tf\%) & UL-94 \\
\hline TETA (alifás) & 23 & HB $(29 \mathrm{~mm} /$ perc) \\
T-58 (cikloalifás) & 20 & HB $(20 \mathrm{~mm} /$ perc) \\
DDM (aromás) & 30 & HB (függ. 1. gyújtás) \\
TEDAP (P-tartalmú) & 29 & HB (függ. 1. gyújtás) \\
\hline
\end{tabular}


A térhálósodás és az éghetőségi jellemzők meghatározása után a DDM-et választottuk térhálósítóként, mivel a legmagasabb üvegesedési hőmérsékletet ezzel az aminnal kaptuk, valamint az éghetőségi jellemzői is kedvezőek.

\subsection{SPE - DDM rendszer égésgátlása}

Az előkísérletek során az égésgátló hatású térhálósító komponens (TEDAP) esetén mért üvegesedési hőmérsékletet lényegesen alacsonyabb volt, mint az aromás, vagy cikloalifás aminok esetén mért, ugyanakkor a DDM-mel térhálósított minták éghetősége közel azonos volt a TEDAP-os mintákéval, ezért az SPE - DDM rendszer additív égésgátlása mellett döntöttünk. A DDM szobahőmérsékleten szilárd vegyület, olvadáspontja 88-92 ${ }^{\circ} \mathrm{C}$, ezért a megfelelő elegyedés érdekében olvadékállapotban kevertük össze az epoxi monomerrel. Amennyiben szilárd égésgátló adalékot alkalmaztunk, a térhálósodási reakció a szemcsék hatására jelentősen felgyorsult, a gyanta pillanatszerűen térhálósodott, így nem lehetett próbatestet önteni. A folyékony halmazállapotú RDP alkalmazása esetén ez a probléma nem jelentkezett, ezért a rendszer égésgátlására ezt a vegyületet használtuk.

A szükséges égésgátló mennyiségét úgy határoztuk meg, hogy az összfoszfortartalmat egy-egy tömegszázalékkal fokozatosan megnöveltük. Ehhez az alkalmazott gyanta (epoxi monomer és térhálósító komponens) mennyiségét csökkentettük annyival, amennyi égésgátló adalékban a megfelelő mennyiségü foszfor található. (100 g-os bekeverésnél 3\% P-tartalmú minta esetén ez azt jelenti, hogy a gyanta mennyisége 72,25 g, az égésgátlóként alkalmazott RDP pedig 27,75 g.) A mért oxigénindex és UL-94 eredményeket a 4 . táblázat tartalmazza.

4. táblázat. SPE - DDM minták éghetősége

\begin{tabular}{lll}
\hline Minta & OI (tf\%) & UL-94 \\
\hline SPE-DDM referencia & 30 & HB (függ. 1. gyújtás) \\
SPE-DDM-RDP 1\%P & 35 & HB (függ. 2. gyújtás) \\
SPE-DDM-RDP 2\%P & 37 & $\mathrm{~V}-1$ \\
SPE-DDM-RDP 3\%P & 38 & $\mathrm{~V}-0$ \\
\hline
\end{tabular}

A táblázat adatai alapján megállapítható, hogy növekvő P-tartalommal fokozatosan, de csökkenő mértékben nő a minták oxigénindexe. A legnagyobb lépcső a referencia minta és az 1\%-os között figyelhető meg: $1 \%$ foszforatom bevitele a rendszerbe $5 \mathrm{tf} \%$-kal növelte meg az OI-t, míg 3\% P-vel mindösszesen további három $\mathrm{tf} \%$-ot nőtt a minta oxigénindexe. UL-94-es vizsgálat során 1\% P alkalmazása esetén a besorolás HB marad, bár a függőleges vizsgálat során csak a 2. gyújtás után ég befogásig a próbatest. $2 \%$ esetén a besorolás V-1-re javul, de a legjobb, V-0 fokozat eléréséhez szükséges a 3\% foszforatom bevitele a rendszerbe.

\section{3. $\mathrm{SPE}-\mathrm{T}-58$ rendszer égésgátlása}

A folyékony halmazállapotú RDP égésgátlóval az SPE DDM rendszer égésgátlása sikeres volt, ugyanakkor a térhálósító relatíve magas olvadáspontja miatt nagy méretben nehezen kezelhető elegyet kaptunk. A további kísérleteket ezért az üvegesedési átmeneti hőmérséklet szempontjából kedvezőbb cikloalifás T-58 alkalmazásával végeztük. Korábbi tapasztalatok szerint epoxigyanták esetén $3 \%$ foszforatom alkalmazásával megfelelő égésgátlás érhető el, ${ }^{13}$ ezért az egyes égésgátlók felhasználásával 3\% P-tartalmú mintákat állítottunk elő, ${ }^{14,15}$ kivéve a DXM esetében, ahol a 3\% P-tartalmú minta nagy viszkozitása lehetetlenné tette a próbatestek elkészítését.

\subsubsection{Termikus stabilitás}

$\mathrm{Az}$ egyes égésgátolt minták termikus stabilitását TGA mérésekkel határoztuk meg, inert $\mathrm{N}_{2}$ atmoszférában. Az 1 . ábra a különböző minták hőbomlásának kezdetéről ad képet, míg a mérési adatokat az 5. táblázat tartalmazza.

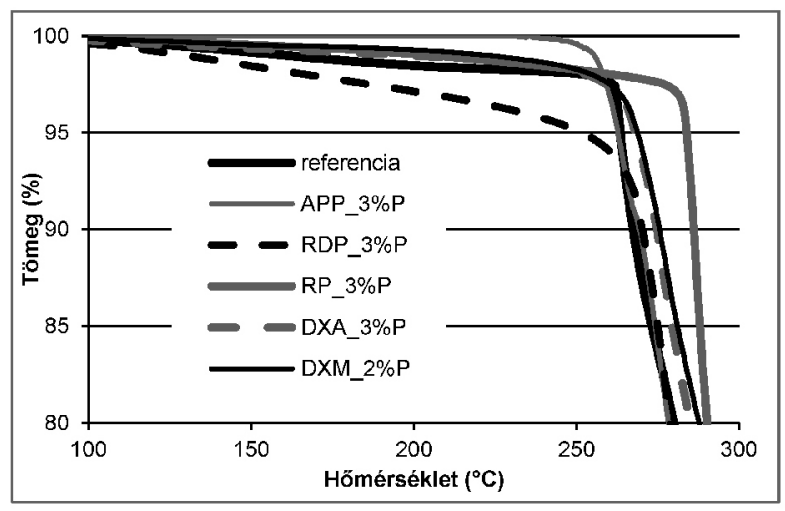

1. ábra. Az égésgátolt SPE - T-58 minták hőbomlásának kezdete

Az 1. ábrán bemutatott görbék közül kitünik, hogy a vörös foszfort tartalmazó minta bomlása közel $20^{\circ} \mathrm{C}$-kal magasabb hőmérsékleten kezdődik a többi mintához képest, azonban a bomlás hirtelen zajlik, a legnagyobb bomlási sebességet az RP esetén tapasztaltuk, ami (a referencia mintához hasonlóan) egybeesik a bomlás megindulásával. A többi égésgátló adalék hatására a bomlás lényegesen lassabban, elnyújtottan zajlott. A leglassabb bomlás az APP esetén volt tapasztalható, a referenciához képest közel harmadára esett vissza a tömegcsökkenés maximális sebessége. Az 50\%-os tömegcsökkenéshez tartozó hömérsékletek alapján megállapítható, hogy az égésgátlók hatásra (az RDP kivételével) minden esetben nőtt ez az érték, ami egyértelműen a bomlást késleltető hatásnak tudható be. A maximális bomlási sebességhez tartozó hőmérsékletek az égésgátolt minták esetében jellemzően $10-12^{\circ} \mathrm{C}-\mathrm{kal}$ magasabbak a referencia gyantáénál, az RP alkalmazásával azonban $25^{\circ} \mathrm{C}$-kal magasabb ez az érték. Ez alapján arra következtethetünk, hogy a vörös foszfor hatékonyan késlelteti a bomlás megindulását, ugyanakkor magasabb hőmérsékleten a gátló hatása nem érvényesül, így elnyújtott, kiegyensúlyozott tömegcsökkenés helyett, és hirtelen nagy mennyiségü bomlástermék keletkezik. 
5. táblázat. 3\% P-tartalmú SPE - T-58 minták termogravimetriai eredményei

\begin{tabular}{llllll}
\hline Minta & $\begin{array}{l}\mathrm{T}_{-5 \%} \\
\left({ }^{\circ} \mathrm{C}\right)\end{array}$ & $\begin{array}{l}\mathrm{T}_{-50 \%} \\
\left({ }^{\circ} \mathrm{C}\right)\end{array}$ & $\begin{array}{l}\mathrm{dTG}_{\max } \\
\left(\% /{ }^{\circ} \mathrm{C}\right)\end{array}$ & $\begin{array}{l}\mathrm{T}_{\mathrm{dTGmax}} \\
\left({ }^{\circ} \mathrm{C}\right)\end{array}$ & $\begin{array}{l}\text { maradék } \\
(\%)\end{array}$ \\
\hline Referencia & 263,5 & 322,1 & $-1,5$ & 263,2 & 5,6 \\
APP 3\%P & 262,7 & 330,2 & $-0,6$ & $27,5,7$ & 23,2 \\
RDP 3\%P & 250,7 & 309,4 & $-1,5$ & 277,3 & 16,6 \\
RP 3\%P & 284,0 & 328,1 & $-2,3$ & 288,1 & 17,7 \\
DXA 3\%P & 268,1 & 330,9 & $-1,0$ & 277,9 & 10,6 \\
DXM 2\%P* & 268,9 & 344,6 & $-0,9$ & 277,6 & 11,5 \\
\hline
\end{tabular}

*legnagyobb elérhető P-tartalom

$\mathrm{T}_{-5 \%}: 5 \%$ tömegcsökkenéshez tartozó hőmérséklet; $\mathrm{T}_{-50 \%}: 50 \%$ tömegcsökkenéshez tartozó hőmérséklet; $\mathrm{dTG}_{\max }$ : tömegcsökkenés maximális sebessége; $\mathrm{T}_{\mathrm{dTG} \max }$ : $\mathrm{dTG}_{\max }$ hoz tartozó hőmérséklet

A $800^{\circ} \mathrm{C}$-on mért maradék tömeg minden égésgátolt rendszer esetében legalább kétszerese a referencia gyantáénak, a legnagyobb növekedést az APP esetében tapasztaltuk: 5,6\%-ról 23,2\%-ra nőtt a szenes maradék mennyisége.

\subsection{2. Éghetőségi vizsgálatok}

Az egyes égésgátlókkal adalékolt minták oxigénindex értékét és UL-94 besorolását a 6 . táblázat tartalmazza.

6. táblázat. $3 \%$ P-tartalmú SPE - T-58 minták éghetősége

\begin{tabular}{lll}
\hline Minta & $\mathrm{OI}(\mathrm{tf} \%)$ & $\mathrm{UL}-94$ \\
\hline Referencia & 20 & $\mathrm{HB}(20 \mathrm{~mm} /$ perc) \\
APP 3\%P & 31 & $\mathrm{HB}$ (függ. 2. gyújtás) \\
RDP 3\%P & 28 & $\mathrm{HB}$ (függ. 2. gyújtás) \\
RP 3\%P & 25 & $\mathrm{~V}-0$ \\
DXA 3\%P & 29 & $\mathrm{~V}-0$ \\
DXM 2\%P* & 29 & $\mathrm{HB}$ (függ. 2. gyújtás) \\
\hline
\end{tabular}

*legnagyobb elérhető P-tartalom

A legnagyobb OI-t az APP-vel égésgátolt minta érte el, a referencia 20 tf\%-hoz képes 11\%-ot javult ez az érték. A DOPO-sav származékok esetében ettől nem sokkal kisebb, 29 tf\%-os értékeket mértünk, azonban megjegyzendö, hogy a DXM esetén mindezt 2\% foszfortartalom mellett. UL-94 vizsgálati módszer szerinti V-0 (önkioltó) besorolást mindösszesen két esetben tapasztaltunk: a vörös foszfor (RP), illetve a DXA alkalmazása során. A szakirodalmi ismeretek $^{13}$ alapján meglepő eredmény, hogy a $3 \%$ P-tartalom ellenére nem sikerült V-0 besorolást elérni az APP és az RDP alkalmazásával. ${ }^{14,15}$

A kaloriméteres éghetőségvizsgálat során regisztrált görbék lefutását a 2. ábra, a pontos adatokat pedig a 7 . táblázat tartalmazza.

Az eredmények alapján megállapítható, hogy az égésgátlók hatására a hőkibocsátás maximális értéke átlagosan 30-50\%-ot csökken. Az UL-94 vizsgálati módszer szerinti V-0 besorolás ellenére a vörös foszforral adalékolt minta esetében tapasztaltuk a legkisebb hatást, a begyulladásig eltelt idő a felére csökkent a referenciához képest, és a hőkibocsátás maximális értéke (pHRR, peak of heat release rate) is lényegesen hamarabb jelentkezik. A DOPO-származékok esetében is hasonló tendenciákat tapasztaltunk, esetükben azonban valamelyest csökkent a pHRR. Az RDP és az APP esetében tapasztaltuk a legkisebb hőkibocsátás értékeket, valamint a begyulladásig eltelt idő nem sokkal marad el a referencia esetében mért értéktől.

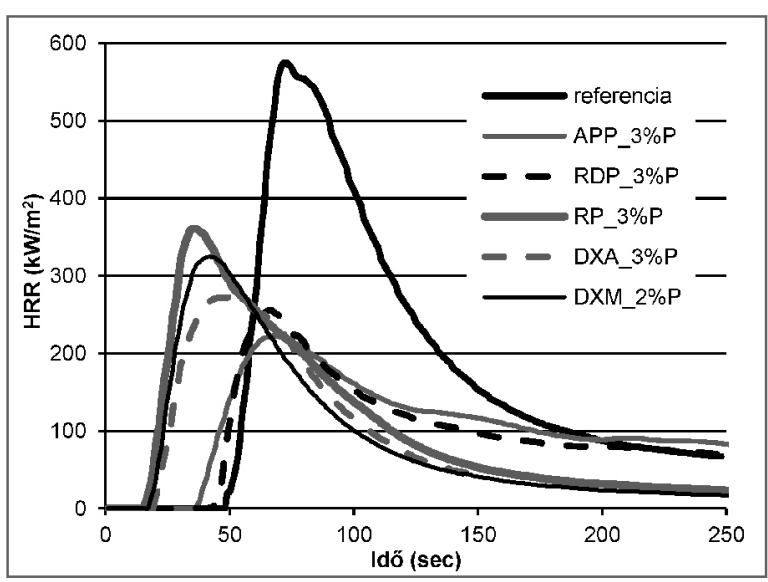

2. ábra. Az egyes égésgátlókkal adalékolt minták hőkibocsátása

Az égés utáni maradék tömegek (6. táblázat) esetében is megállapítható, hogy az APP és az RDP alkalmazásával érhető el a legjobb eredmény, utóbbi esetben a minta kiindulási tömegének több mint negyede maradt meg elszenesedett formában. Bár a TGA eredmények alapján (ld. 3.3.1. fejezet) a vörös foszfor számottevő szenesítő hatást fejt ki a szilárd fázisban, minden valószínüség szerint ez a védőréteg oxigén jelenlétében elbomlik.

7. táblázat. Égésgátolt SPE - T-58 minták kaloriméteres éghetőségvizsgálatának eredménye

\begin{tabular}{llll}
\hline Minta & $\begin{array}{l}\text { TTI } \\
(\mathrm{sec})\end{array}$ & $\begin{array}{l}\mathrm{pHRR} \\
\left(\mathrm{kW} / \mathrm{m}^{2}\right)\end{array}$ & $\begin{array}{l}\text { maradék } \\
(\%)\end{array}$ \\
\hline Referencia & 45 & 575 & $<1$ \\
APP 3\%P & 39 & 173 & 17,0 \\
RDP 3\%P & 43 & 255 & 28,4 \\
RP 3\%P & 16 & 361 & 4,3 \\
DXA 3\%P & 21 & 272 & 11,0 \\
DXM 2\%P & 15 & 325 & 8,7 \\
\hline
\end{tabular}

Az egyes égésgátlók esetében azonos P-tartalom mellett elért szignifikánsan különböző eredmények megértéséhez az égésgátlók hatásmechanizmusát kell megvizsgálni. Az ammónium polifoszfát az ún. felhabosodó égésgátlók tipikus képviselöje: szilárd fázisban a foszfát-részböl keletkezö polifoszforsav révén hő hatására a polimer szenesedése következik be, míg a keletkező N-tartalmú gázok ezt az elszenesedett védőréteget felhabosítják, ezzel egy a hö- és gáztranszportot jól gátló felületi védelmet hozva létre. ${ }^{16} \mathrm{~A}$ vörös foszfor esetében nem beszélhetünk felhabosodásról, ez 
az égésgátló kizárólag a szilárd fázisban tud müködni. A DOPO-sav ammónium sója a gyártó specifikációja szerint a gázfázisban fejti ki hatását, a molekulából keletkező P-tartalmú gyökök az égés terjedéséért felelős hidrogén- és hidroxid gyökökkel reagálva lassítják a láng terjedését. Ezzel szemben a DXM esetében a DOPO-sav sóját alkotó melamin révén jelentős szilárd fázisú hatás is jelentkezik. Az RDP a szakirodalmi adatok ${ }^{17}$ alapján leginkább a gázfázisban hat, kisebb mértékben a szilárd fázisban is tud reagálni.

\subsection{3. Égésgátlók kombinálása}

A 6. táblázatból látszik, hogy bár a szakirodalom szerint $3 \%$ foszfor alkalmazása elegendő a V-0 fokozat eléréséhez, az APP és az RDP esetében ez nem sikerült, ezért a két égésgátló kombinálásával is előállítottunk $3 \%$ foszfortartalmú mintákat. Amennyiben 1\% foszfort RDP-vel, és 2\%-ot APP-vel vittünk be a rendszerbe, az UL-94 besorolás HB maradt, viszont ezt az arányt megfordítva, illetve ha a két adalékkal egyforma koncentrációban juttattunk P-t a gyantába, sikerült elérni a V-0 önkioltó fokozatot, és 33-34-es OI-t mértünk (8. táblázat).

8. táblázat. SPE - T-58 rendszer égésgátlása kombinált additív égésgátlókkal

\begin{tabular}{lll}
\hline Égésgátlo összetétel & OI (tf\%) & UL-94 \\
\hline RDP 1\%P+APP 2\%P & 29 & HB (függ. 2. gyújtás) \\
RDP 1,5\%P+APP $1,5 \% \mathrm{P}$ & 33 & $\mathrm{~V}-0$ \\
RDP 2\%P+APP 1\%P & 34 & $\mathrm{~V}-0$ \\
\hline
\end{tabular}

Meglepőnek tünhet, hogy ugyanakkora foszfortartalom mellett ennyire eltérő eredményeket kaptunk. A magyarázathoz az égésgátlók szilárd- illetve gázfázisban kifejtett hatását vizsgáltuk. A gázfázisú hatást a kutatócsoportban korábban kifejlesztett lézer pirolízis (LP)-FTIR csatolt módszer ${ }^{18}$ alkalmazásával, míg a szilárd fázisút az égés utáni szenes maradékokon végzett ATR-IR méréssel térképeztük fel ${ }^{14}$. Az eredményekből egyértelmüvé vált, hogy megfelelő égésgátlás (V-0 fokozat) abban az esetben érhető el, amennyiben a szilárd- és a gázfázisban kifejtett hatás kiegyensúlyozott.

\subsection{Szálerősített SPE - T-58 rendszer égésgátlása}

Megújuló nyersanyagforrásból származó mátrixok esetén kézenfekvő megoldás a biokompozit erősítő szálait is megújuló forrásból választani. Amennyiben piaci termék kifejlesztése a cél, a mechanikai és éghetőségi tulajdonságok mellett fontos szempont a gazdaságosság, a gyártás termelékenysége, valamint az esztétikai megjelenés is. Az egyes égésgátlók előnyeit-hátrányait összevetve a lenszövet erősítésű kompozit égésgátlására az APP-t választottuk.

A természetes szálak éghetősége, valamint a szálerősítésre jellemző ún. kanóc effektus miatt az erősítő lenszövetet égésgátló kezelésnek vetettük alá. Az optimális megoldást diammónium-foszfát és bórsav 4:1 arányú keverékével értük el. ${ }^{19} \mathrm{Az}$ előállított biokompozitok éghetőségi tulajdonságait a 9. táblázat tartalmazza.
9. táblázat. Lenszövet erősítésű biokompozitok éghetőségi tulajdonságai

\begin{tabular}{llll}
\hline Minta & $\begin{array}{l}\text { OI } \\
(\mathrm{tf} \%)\end{array}$ & UL-94 & $\begin{array}{l}\mathrm{pHRR} \\
\left(\mathrm{kW} / \mathrm{m}^{2}\right)\end{array}$ \\
\hline SPE + ref. szövet & 24 & IIB (17,8 mm/perc) & 358 \\
SPE + kezelt szövet & 30 & HB (függ. 1. gyújtás) & 215 \\
SPE-APP + ref szövet & 30 & HB (függ. 2. gyújtás) & 136 \\
SPE-APP + kezelt szövet & 33 & $\mathrm{~V}-0$ & 118 \\
\hline
\end{tabular}

Az eredményekböl egyértelmüen kitünik, hogy a legjobb eredmény az égésgátolt mátrix égésgátolt szövettel történő társításával érhető el. Bár az OI értéke jelentősen nőtt függetlenül attól, hogy a mátrix vagy a szál volt égésgátolva, megfelelően alacsony hőkibocsátás és V-0 besorolás eléréséhez mindkettőre szükség volt.

Szénszál erősítésű kompozitok esetén az APP és RDP kombinálásából eredő szinergikus hatást (ld. 3.3.3. fejezet) szerettük volna kihasználni. Az előállított szénszálas minták éghetőségi tulajdonságait a 10. táblázat foglalja össze.

10. táblázat. Szénszálas kompozitok éghetőségi tulajdonságai

\begin{tabular}{llll}
\hline Minta & $\begin{array}{l}\text { OI } \\
(\mathrm{tf} \%)\end{array}$ & UL-94 & $\begin{array}{l}\mathrm{pHRR} \\
\left(\mathrm{kW} / \mathrm{m}^{2}\right)\end{array}$ \\
\hline SPE kompozit ref. & 24 & $\mathrm{HB}$ (függ. 1. gyújtás) & 163 \\
$\begin{array}{l}\text { RDP 3\%P kompozit } \\
\text { APP 3\%P kompozit }\end{array}$ & 27 & $\mathrm{~V}-1$ & 88 \\
$\begin{array}{l}\text { RDP 1,5\%P+ } \\
\text { kompozit 1,5\%P }\end{array}$ & 31 & $\mathrm{HB}$ (függ. 2. gyújtás) & 103 \\
$\begin{array}{l}\text { RDP 2\%P+APP 1\%P } \\
\text { kompozit }\end{array}$ & 32 & $\mathrm{~V}-1$ & 91 \\
\hline
\end{tabular}

A szénszálas kompozitok esetében a legjobb elért eredmény UL-94 szerinti V-1 besorolás volt, ami a szénszálak jó hővezetésével, valamint az általuk okozott kanóc effektussal magyarázható. Ebben a rendszerben az RDP égésgátló önmagában alkalmazva hasonlóan jó eredményt ért el, mint a kombinált rendszer, azonban mechanikai szempontból ez utóbbi kedvezőbbnek bizonyult: pl. a szakítószilárdsága közel 100 MPa-lal nagyobb volt, mint az RDP tartalmú kompozité (948,1 illetve 851,2 MPa). ${ }^{20}$

\section{Köszönetnyilvánítás}

A szerző köszönettel tartozik a segítségért a következő személyeknek: Toldy Andrea, Marosi György, Bordácsné Bocz Katalin, Igricz Tamás, Niedermann Péter. A munka eredményei a következő projektekhez kapcsolódnak: OTKA K-112644, Európai Unió Hetedik Keretprogramjának (FP7/2007-2013) Clean Sky JTI 298090 szerződésszámú alprojektje, valamint az NFÜ EU_BONUS_12-12012-0026-os azonosítójú támogatása. A szerző köszöni az MTA Prémium posztdoktori program támogatását. 


\section{Hivatkozások}

1. Güner, F.S.; Yađcý, Y.; Erciyes, A.T. Prog. Polym. Sci. 2006, 31, 633-670. https://doi.org/10.1016/j.progpolymsci.2006.07.001

2. Earls, J.D.; White, J.E.; López, L.C.; Lysenko, Z.; Dettloff, M.L.; Null, M.J. Polymer 2007, 48, 712-719. https://doi.org/10.1016/j.polymer.2006.11.060

3. Zhao, B.; Chen, G.; Liu, Y.; Hu, K.; Wu, R. J. Mater. Sci. Lett. 2001, 20, 859-862. https://doi.org/10.1023/A:1010975132530

4. Kishi, H.; Akamatsu, Y.; Noguchi, M.; Fujita, A.; Matsuda, S.; Nishida, H. J. Appl. Polym. Sci. 2010, 120, 745-751. https://doi.org/10.1002/app.33199

5. Raquez, J.M.; Deléglise, M.; Lacrampe, M.F.; Krawczak, P. Prog. Polym. Sci. 2010, 35, 487-509.

https://doi.org/10.1016/j.progpolymsci.2010.01.001

6. Chrysanthos, M.; Galy, J.; Pascault, J.P. Polymer 2011, 52, 3611-3620. https://doi.org/10.1016/j.polymer.2011.06.001

7. Hong, J.; Radojčić, D.; Ionescu, M., Petrović, Z.S.; Eastwood, E. Polym. Chem. 2014, 5, 5360-5368. https://doi.org/10.1039/C4PY00514G

8. Rapi, Z.; Szolnoki. B.; Bakó, P.; Niedermann, P.; Toldy, A.; Bodzay, B.; Keglevich, G.; Marosi, G. Eur. Poly. J. 2015, 67, 375-382.

https://doi.org/10.1016/j.eurpolymj.2014.09.025

9. Niedermann, P.; Szebényi, G.; Toldy, A. Express Polym. Lett. 2015, 9, 85-94.

https://doi.org/10.3144/expresspolymlett.2015.10
10. Chung, Y.; Kim, Y.; Kim, S. J. Ind. Eng. Chem. 2009, 15, 888-893. https://doi.org/10.1016/j.jiec.2009.09.018

11. Gérard, C.; Fontaine, G.; Bellayer, S.; Bourbigot, S. Polym. Degrad. Stabil. 2012, 97, 1366-1386.

https://doi.org/10.1016/j.polymdegradstab.2012.05.025

12. Toldy, A.; Szolnoki, B.; Csontos, I.; Marosi, G. J. Appl. Polym. Sci. 2014, 131, 40105 https://doi.org/10.1002/app.40105

13. Hergenrother, P.M.; Thompson, C.M.; Smith Jr, J.G., Connell, J.W.; Hinkley, J.A.; Lyon, R.E.; Moulton, R. Polymer, 2005, 46, 5012-5024. https://doi.org/10.1016/j.polymer.2005.04.025

14. Szolnoki, B.; Bocz, K.; Marosi, G.; Toldy, A. Polymers 2016, 8, $322 \mathrm{https} / / /$ doi.org/10.3390/polym 8090322

15. Szolnoki, B.; Pankucsi, O.F.; Toldy, A.; Marosi, G. Polimerek 2016, 2, 265-269.

16. Camino, G.; Lomakin, S. In Fire retardant materials; Horrocks, A.R., Price D., Ed.; Woodhead Publishing Limited: Cambridge, 2001; pp 318-336. https://doi.org/10.1533/9781855737464.318

17. Pawlowski, K.H.; Schartel, B. Polym. Int. 2007, 56, 1404-1414. https://doi.org/10.1002/pi.2290

18. Bodzay, B.; Marosföi, B.B.; Igricz, T.; Bocz, K.; Marosi, G. J. Anal. Appl. Pyrol. 2009, 85, 313-320. https://doi.org/10.1016/j.jaap.2008.11.016

19. Pankucsi, O.F. Szakdolgozat, Budapesti Műszaki és Gazdaságtudományi Egyetem, 2015

20. Toldy, A.; Niedermann, P.; Pomázi, Á.; Marosi, G.; Szolnoki, B. Materials 2017, 10, 467

\section{Environmentally friendly flame retardancy of biobased epoxy resin composites}

The development of polymer systems, derived from renewable resources is one of the most frequently investigated research area in the field of materials chemistry and macromolecular chemistry. While in the case of the thermoplastic polymers, the dominance of poly(lactic acid) is doubtless, the optimal candidate of biobased thermosetting material is still missing. Among the materials of carbohydrate origin, the isosorbide-based epoxy monomer is in the focus of the researchers, but until now, no real break-through was reached.

One of the most important criteria of engineering applications of polymers is the decreased flammability. Phosphorus, depending on the molecular structure of the flame retardant (FR), can act both in gas phase, mainly at the beginning of degradation, and later in solid phase, providing advantageous FR effect for biopolymers by this combined mechanism.

In this work, the flame retardancy of commercially available sorbitol-based epoxy resin (sorbitol polyglycidyl ether, SPE) composites is targeted.

As a first step, the most suitable curing agent has been chosen based on DSC measurements. Although the flame retardancy of the DDM-cured SPE resin was successful, due to processing difficulties the further experiments were carried out applying a cycloaliphatic amine type hardener (T-58). The applied additive type flame retardants were: ammonium polyphosphate (APP), resorcinol bis(diphenyl phosphate) (RDP), red phosphorus (RP) and DOPO (9,10-dihydro-9-

oxa-10-phosphaphenanthrene-10-oxide)-derivatives (DXA, ammonium salt and DXM, melamine salt).

From the SPE-based bioepoxy 3\% phosphorus-containing matrix samples were prepared and tested. To reach the same P-loading, different amounts of FRs were added, according to their P-content. In the case of the thermogravimetric analysis, the application of RP resulted in significantly (by $20^{\circ} \mathrm{C}$ ) increased thermal stability, however the degradation was faster, than in the case of the reference. The RDP somewhat lowered the $\mathrm{T}_{-5 \%}$ values, due to the less stable phosphorus ester bonds. All FRs shifted the $\mathrm{dTG}_{\max }$ to higher temperatures. The amount of the charred residues is increasing with the FR content, but to different extents depending on the type of FR. The highest values were reached with the application of APP. Surprisingly, only HB classification of UL-94 test was reached with the application of APP and RDP. V-0 was reached in the case of RP and DXA, while DXM resulted in HB, due to the lower P-content of the sample. In the meantime, the highest LOI value was reached in the case of APP. The V-0 RP composition, however, has an LOI of as low as $25 \mathrm{~V} / \mathrm{V} \%$. Regarding the cone calorimeter results, the lowest HRR belongs to the APP-containing sample, while the V-0 compositions (RP and DXA) show poorer flame retardant effect in this case.

When applied alone, both the RDP and APP-containing formulations showed increased LOI values but their UL-94 
ratings remained HB. Phosphorus content of $3 \%$ is generally sufficient to reach appropriate flame retardancy, thus, mixed FR formulations with combined RDP and APP, have been also prepared. V-0 rating was reached when at least $1.5 \% \mathrm{P}$ from RDP and 1\% P from APP, respectively, was present in the system (in addition to the complementing FR added to reach 3\% P-content). The suspected balanced gas and solid-phase mechanism was first investigated by LP-FTIR measurements, which indicated no gas-phase effect in the case of sample containing only APP, while increasing the RDP content lead to increased amount of $\mathrm{P}$ species among the gas-phase degradation products. RDP increased the aromatic content of the residue according to its ATR-IR spectra. On the other hand the dominance of the solid-phase mechanism in case of APP-containing samples was also confirmed.

All-bio composites can be prepared by reinforcing bioresins with natural fibres; however, several issues hinder their dispersion in high-tech applications, including their flammability. An industrially suitable FR composition of SPE bioepoxy resin reinforced with flax fabrics was also elaborated. For effective flame retardancy, both the matrix and the fabrics were flame retarded. The flame retardant applied in the bioepoxy matrix (APP) was chosen based on the results of 5 different FRs. Also, the composition of the solution for the surface treatment of the fabrics was optimized. Four types of composites have been prepared and tested with reference and FR matrix and with reference and FR reinforcing fabrics. The fully flame retardant composite reaches V-0 UL-94 level, has an LOI of $33 \mathrm{~V} / \mathrm{V} \%$ and significantly decreased heat release, compared to the reference.

In the case of carbon fibre reinforced composites, in contrast to combined formulations in unreinforced matrix, the self-extinguishing $\mathrm{V}-0$ rating was not reached, most probably due to the so called candlewick effect and intumescent-hindering effect of the introduced reinforcing fibres. Further increase of P-content in order to overcome this issue is not reasonable as at higher ratios the plasticizing effect of RDP becomes significant and the aggregation of solid APP particles is more distinct, which all together leads to lower crosslinking density, and impairs the flame retardant and mechanical performance. 